\title{
The midWife's role in lactation care in Poland
}

\author{
Jadwiga Surówkaa ${ }^{1 A, B, C, D, E, F}$, Magdalena Humaj-Grysztar2A,B,C,D,E,F, Renata Madetko 2A,B,C,D,E,F
}

\author{
'Student's Scientific Group of Midwifery Care, Institute of Nursing and Midwifery, Faculty \\ of Health Sciences, Jagiellonian University Medical College, Cracow, Poland \\ 2Department of Basic Midwifery Training, Institute of Nursing and Midwifery, Faculty of Health \\ Sciences, Jagiellonian University Medical College, Cracow, Poland
}

\section{Authors' contribution:}

A. Study design/planning • B. Data collection/entry $\bullet$ C. Data analysis/statistics $\bullet$ D. Data interpretation $\bullet$ E. Preparation of manuscript $\bullet$ F. Literature analysis/search $\bullet$ G. Funds collection

\author{
Address for correspondence: \\ Jadwiga Surówka \\ Student's Scientific Group of Midwifery Care \\ Institute of Nursing and Midwifery \\ Faculty of Health Sciences \\ Jagiellonian University Medical College \\ 58 Zamoyskiego St. \\ 31-523 Cracow, Poland \\ e-mail: jadwiga.surowka@student.uj.edu.pl \\ SUBMITTED: 23.04 .2021 \\ ACCEPTED: 09.06.2021 \\ DOI: https://doi.org/10.5114/ppiel.2021.110452
}

\begin{abstract}
Breast milk is perfectly adapted to the individual nutritional needs of the child. The World Health Organization recommends exclusive natural feeding of infants until they reach 6 months of age. Midwives provide women with lactation support before and after childbirth. Their care continues after discharge from hospital during home visits. Nowadays, most women experience breastfeeding difficulties, indicating the importance of the midwife's role in lactation care. The role of midwives in antenatal care is to provide information on the physiology of lactation and to present the benefits of breastfeeding for the mother and child. An important element of antenatal education is the initial preparation of the pregnant woman for breastfeeding. The role of midwives after delivery is to ensure skin-to-skin contact of the newborn and its mother. They teach the correct way to latch the baby onto the breast and help to choose a proper position for feeding. The community midwife takes care of the women after discharge from hospital. They visit the mother and the baby in their home environment. During home visits, the midwife assesses the newborn's and the mother's health, the newborn's physical development and weight gain, and provides lactation support. The midwife's lactation advice is based on the following: medical interview, observation of the mother's general and mental condition, breast examination, suckling assessment, and evaluation of the breastfeeding efficiency. The midwife provides lactation advice, taking into account the anatomical conditions in the structure of the mother's breast and the child's oral cavity. Key words: midwife, lactation, breastfeeding, lactation care.
\end{abstract}

\section{INTRODUCTION}

Regardless of age, race, or latitude and longitude, breastfeeding is the most appropriate way to feed children. Breast milk provides the newborn with the basic building and bioactive components, including proteins directly and indirectly involved in immunity [1]. Breastfeeding is also an excellent way of hydrating a child even in a dry and hot climate newborns do not require supplementary feeding [2]. Colostrum is the first milk that the newborn consumes immediately after birth. Many benefits of administering colostrum to newborns in the first minutes after birth have been proven. Not only full-term newborns consume colostrum, but also premature babies - if their health allows it [3]. It provides immune protection for the premature baby - it reduces the risk of sepsis, necrotizing enterocolitis, and hospital infections [4].

The World Health Organization (WHO) also pays attention to this and recommends the exclusive natural feeding of children until they reach 6 months of age, and then continued breastfeeding through the first year and up to 2 years of age [2]. Unfortunately, only $38 \%$ of infants are exclusively breastfed, and the goal set for 2025 is to increase the rate of exclusive breastfeeding to at least $50 \%$ in the first 6 months [5]. The WHO and the United Nations International Children's Emergency Fund (UNICEF) have created a worldwide Baby-Friendly Hospital Initiative and institute "Ten Steps to Successful Breastfeeding" to re-establish proper nutrition to children. The Baby-Friendly Hospital Initiative is considered a guarantee of the facility's evidence-based policy in terms of breastfeeding support and high-quality perinatal care [6]. There are as many as 95 hospitals with this title in Poland [7].

There are many factors that determine the success of lactation. Delivery completed by caesarean section, routine feeding of babies with artificial formula, insufficient knowledge of medical staff, or non-compliance with the guidelines may result in premature cessation of breastfeeding. Antenatal education in combination with postnatal interventions is the most effective in 
prolonging the duration of breastfeeding. The success of natural feeding is measured by evaluating the duration of exclusive breastfeeding [8]. Nowadays, most women experience breastfeeding difficulties. It is important that the midwife provides adequate support to the mother at this time. Due to difficulties and a lack of adequate support, many mothers who undertake breastfeeding do not continue breastfeeding sufficiently long despite being willing to do so. In accordance with the Organization Standard of Perinatal Care applicable from 1 January 2019 the midwife provides lactation support to the woman before childbirth, after childbirth, and after discharge from the hospital. Compliance with the standard is aimed at increasing the number of exclusively breastfed children by ensuring appropriate conditions for proper lactation [8]. Midwives who practice evidence-based methods are those who promote initiation of breastfeeding and increase the breastfeeding duration of their patients by using their knowledge and skills in the promotion, support, and guidance of nursing the mother and infant [9]. The aim of the following review is to describe the midwife's role in lactation care in Poland.

\section{ANTENATAL CARE}

The community midwife carries out prenatal education amongst pregnant women from the $21^{\text {st }}$ week of pregnancy. During the cyclical meetings, the midwife educates the mother on topics related with the course of pregnancy, lifestyle during this period, and preparation for childbirth and parenthood. An important element of antenatal education is the initial preparation of the pregnant woman for breastfeeding. The framework programme for antenatal education in the matter of labour involves skin-to-skin contact and the initiation of breastfeeding. The framework programme in the matter of postpartum period involves breastfeeding and lactation support, including the management of lactation problems [8].

The role of the midwife at this stage is to provide information to the pregnant woman in the field of anatomy of the mammary gland and its function during breastfeeding. The midwife explains the changes occurring in the gland under the influence of pregnancy. Making pregnant women aware that the milk production process in the mammary gland begins much earlier before the childbirth [8]. It is important to pay attention to the mechanisms regulating the lactation process. Two hormones play a major role: oxytocin and prolactin. The role of the midwife is to point out factors that can stimulate or inhibit the lactation process. One of the stimuli is the stimulation of the mother's mammary papilla by the newborn. It stimulates the secretion of oxytocin, the hormone responsible for milk ejection. Oxytocin levels increase not only by nipple stimulation, but also by the sight of the child, or hearing his/her crying. Factors inhibiting oxytocin secretion are severe pain felt by the mother, bad thoughts, uncertainty, and lack of faith in one's own skills [10].

That is why early prenatal education of women is so important. It aims not only to equip the pregnant woman with practical skills and knowledge, but also to encourage and reassure her that despite the difficulties she may encounter during breastfeeding she is able to overcome them.

Antenatal education includes promotion of breastfeeding. The midwife encourages pregnant woman to breastfeed by explaining the type and function of breast milk ingredients. The midwife pays special attention to the composition of colostrum, the first milk taken by the newborn [8]. It is characterized by a high content of $\beta$-carotene, which gives it colour from yellow to even greenish. It contains compounds such as immunoglobulin A, leukocytes, vitamins $A$ and E, protein, zinc, and growth factor [10].

Afterwards, the midwife presents the benefits of breastfeeding for the child and mother. The beneficial factors for the mother in postpartum period include the following: accelerated involution of the uterus, faster weight loss and return to a pre-pregnancy figure, and reduced risk of postpartum depression. Breastfeeding reduces the risk of breast and ovarian cancer; it also reduces the risk of osteoporosis in the postmenopausal period [11]. Some of the advantages of breastfeeding for the child are reduced risk of diarrhoea and digestive system infections, and reduced risk of otitis media and respiratory and urinary tract infections. Breastfed children are less likely to be overweight, obese, and allergic in adulthood. Breastfeeding also supports the child's speech development [10].

One form of antenatal education provided by midwives comprises workshops focusing on the technical aspects of breastfeeding. By using a doll the midwife can teach a variety of correct breastfeeding positions and show how the newborn should latch on to the breast. At this stage of preparation, the midwife explains the characteristics of proper suction and food intake by the newborn.

\section{CARE AFTER CHILDBIRTH/POSTPARTUM CARE}

The procedure in the third stage of labour is to ensure skin-to-skin contact, to observe the contact between the mother and the newborn, and to assist in latching the newborn on to the breast. It is the midwife's role to ensure 2 hours of skin-to-skin contact of the newborn and its mother immediately after birth, if the condition of both allows it, in the fourth stage of labour [8]. The midwife makes sure that this is continuous contact, without interruption for anthropometric measurements. During this time, the mid- 
wife supervises the first breastfeeding. She helps the mother to choose the correct, comfortable position for feeding and supports her in identifying the moment when the newborn is ready to latch. Verbal instruction is recommended - without touching the breast and the baby's head, if there is no need. Skin-to-skin contact is vital in the context of further milk production - it stimulates the synthesis of hormones responsible for milk production and outflow [12].

The first breastfeeding should start at the latest 30-60 minutes after giving birth and continue until it is finished naturally. In the case of delivery by caesarean section, breastfeeding should be implemented in the operating room. Although the first feeding may be delayed, it is important to ensure that the mother and baby are in constant contact, with skin-to-skin contact as soon as possible [13].

The conditions for successful lactation and nutrition of the newborn should be ensured by the midwife, who takes care of the mother and child providing the mother with information that is coherent and consistent with the current knowledge on lactation in terms of the benefits and methods of breastfeeding or feeding by breast milk (bottle, syringe, cup-feeding, finger feeding) [8].

The rooming-in system supports the development of lactation [14]. During hospitalization, midwives from the maternity ward support mothers at the start of breastfeeding. They teach them, among other things, to observe the early signs of hunger in a child, in the form of awakening, looking around, clicking its tongue, and opening its mouth [15]. They present the main rules of breastfeeding on demand such as feeding the baby as often as it shows signs of hunger, and feeding as long and often as the child needs it. During the initiation of breastfeeding, attempts should be made to latch the newborn on to the breast even over a dozen times a day (to achieve 8-12 effective feedings) for at least 15 minutes to each breast, and if the newborn does not wake up, it should be awakened for feeding after 3-4 hours, counting from the beginning of the last feeding, with the exception of the first 12 hours of a child's life, when the newborn does not need to wake up every 3 hours due to reduced activity [13].

Interference with the natural lactation process is associated with a medically justified indication. In accordance with the Organization Standard of Perinatal Care, medical interventions should be limited to the necessary ones, including the administration of modified infant formula to the newborn. The administration of artificial milk takes place only on the doctor's prescription or in accordance with the mother's decision, after having previously informed her about the mode of this type of nutrition. Initially, pacifiers should be used with caution or introduced after the period of stabilization of lactation. Pacifier use shortens the breast suckling time. Breastfed infants without indications should not be fed with artificial formula. Newborns should not be supplemented with water or glucose [8].

The midwife teaches the correct way to latch the baby onto the breast and helps to choose a proper position for feeding. The right feeding technique allows the breast to empty properly, which stimulates the production of milk and gives the mother the certainty that she will meet the nutritional needs of the baby [13]. When choosing a position to breastfeed, it is necessary to make sure that the nursing mother is comfortable. Her back should be straight, her head resting, and her legs should rest on the ground. The newborn's tummy should be in contact with the mother's body, and the baby's head, back, and buttocks should be in one line [16]. The midwife draws the mother's attention to the characteristics of a good latch-on of the newborn to the breast. The midwife assesses the suckling ability of the newborn in the maternity or neonatal ward [8].

In the first days after birth, the midwife observes the features of a good latch-on and position at the breast as well as the symptoms of effective and ineffective feeding, in particular the number of feedings, stools and mictions per day, duration and rhythm of the swallowing sound during feeding, and weight gain, so-called indicators of successful feeding. The results of evaluation are recorded in the medical documentation [8].

If breastfeeding is unsuccessful, the midwife diagnoses the problem on the basis of suckling skills and implements current lactation knowledge to enable the newborn to be effectively fed with breastmilk or expressed breastmilk. The correct selection of the feeding method should not increase the risk of problems with breast suckling and the lactation process [8].

The midwife teaches the mother how to manually extract breast milk, especially colostrum, for the newborn. She should take care to provide each mother in need with equipment to obtain breast milk effectively. If full-term or premature newborns cannot be fed their mother's milk, it is recommended that they be given breastmilk from a milk bank. The midwife is also responsible for providing help during lactation stimulation if necessary [8].

During the mother's stay in the maternity ward, she should be informed by the midwife about the most common lactation problems and how to deal with them at home. This includes breast fullness, which occurs most often just after leaving the hospital between 3 and 4 days after childbirth. The mother's breasts can become tender and heavy, which causes discomfort. Nursing mothers also often face the problem of nipple trauma, which is a sign of abnormal latching of the baby to the breast (too shallow), which should be corrected under the supervision of a community midwife $[8,17]$. 
The external medical documentation of the newborn should be prepared, containing information about the dietary recommendations and the necessary specialist consultations on the day of discharge from hospital [8].

In places where pregnant women, mothers, and newborns stay, such as hospitals, infant formulas and infant feeding products should not be advertised. Midwives, while working in medical facilities, should respect these rules. This plays a role in reducing the risk of premature breastfeeding cessation [8].

\section{CARE AFTER DISCHARGE FROM THE HOSPITAL}

A hospital stay under the care of professionals is not enough to initiate and stabilize lactation, so it is especially important to evaluate lactation during community midwife visits, the first of which should take place no longer than 48 hours after discharge from the hospital [9]. After discharge from the hospital, the care of the mother and child is taken up by a community midwife, who carries out a minimum of 4 home visits. During home visits, the midwife assesses the health of the newborn and mother, and the newborn's physical development and weight gain, and provides lactation support [8]. The task of the community midwife is to encourage the mother to undertake natural feeding, to identify any mistakes, and to show support and willingness to help solve any lactation problems.

Lactation advice is based on the following:

1. Conducting a medical interview and establishing contact with the mother. This is especially important because the information obtained from the mother during the interview and the analysis of medical records will allow the midwife to provide holistic care for the mother [16].

2. Observation of the mother's general physical and mental condition. The midwife observes the mother's behaviour and her general appearance. She pays attention to her physical condition: Is the mother well-nourished and properly hydrated? The task of the midwife is to notice any disturbing symptoms like swelling, sweats, shortness of breath, or fever. During conversation, the midwife is able to determine the mother's emotional condition and observe her attitude to the child [16].

3. Breast examination, after obtaining permission. During palpation of the mammary gland the midwife assesses the shape, symmetry, and size of the breast. She also assesses the nipple shape and any damage, and evaluates its flexibility and grip. During the examination special attention is paid to the presence of sclerosis, oedema, and tumours. The examination includes palpating the axillary lymph nodes. This procedure is a good way to re- mind the mother of the importance of performing a breast self-examination once a month $[8,16]$.

4. Suckling assessment, taking into account the anatomy of the newborn's oral cavity. The midwife during the examination of the newborn's oral cavity pays attention to the palate construction, mandible location, lip tension, and tongue mobility. It is important to pay attention to the lingual frenulum. A tongue with a shortened lingual frenulum has a limited range of mobility, which means that the child cannot properly latch onto the breast. The midwife determines the presence or absence of the sucking reflex and evaluates the suckling characteristics [16, 18].

5. Observation of the breastfeeding with the identification of abnormalities in the newborn's latching ability. The midwife sits next to the mother and, maintaining eye contact, assesses the act of feeding [16].

6. Evaluation of breastfeeding efficiency. The effectiveness of feeding can be determined by asking specific questions. Essential information includes the frequency of feedings per day and how many times the mother breastfeeds at night. The number of stools the newborn makes per day and how many diapers it soaks, as well as how many grams per day a child gains from the lowest weight or last measurement [16]. Important information also includes the presence of functional intestinal disorders, gastroesophageal reflux disease, or colic pain [8].

In the case of health problems in the mother or child, the solution of which is beyond the competence of the midwife, the midwife informs the patient about the need for intervention of other specialists, such as a neurologopedist, physiotherapist, or doctor [8].

\section{MIDWIVES' POSTGRADUATE EDUCATION IN THE FIELD OF LACTATION}

Supporting mothers during the initiation breastfeeding, maintaining and managing many difficulties, requires good listening skills and supportive supervision, often beyond basic knowledge and experience [19]. It is also the midwife's obligation to constantly update their abilities and use the opportunities of postgraduate education, which will allow for the provision of lactation care at an increasingly high level [20]. The midwife can attend a specialist course "Education and support of women during lactation", which is organised by the Centre for Postgraduate Training of Nurses and Midwives. This education option enables the midwife to work as a lactation educator [21]. Completing a course as part of postgraduate education organized by the Centre for The Study of Lactation "Problems during lactation" gives the midwife the title of a Certified Lactation Consultant, and the learn- 
ing outcome is the possibility of providing a specialist lactation advisory service [22]. Midwives also have the opportunity to obtain the title of International Breastfeeding Certified Lactation Consultant (IBCLC), confirmed by an international certificate, which allows them to work with lactation around the world [23].

\section{CONCLUSIONS}

Although breastfeeding is a natural and physiological process, it can be problematic. Lactation is a process that takes time. Any mistakes that are noticed and their correction under the supervision of a midwife increases the chance of effective breastfeeding.

The midwife who is caring for a mother and a child before and after childbirth should have professional knowledge of lactation physiology and should know the principles of proceeding during lactation and the causes of proper course in order to take effective measures to help mothers with optimal long-term natural breastfeeding.

\section{Disclosure}

The authors declare no conflict of interest.

\section{References}

1. Tripathy S, Singh S, Das SK. Potential of breastmilk in stem cell research. Cell Tissue Bank 2019; 20: 467-488.

2. Guideline: protecting, promoting and supporting breastfeeding in facilities providing maternity and newborn services. World Health Organization, Geneva 2017 [cit. 02.04.2020]. Available from: https://apps.who.int/iris/bitstream/hand le/10665/259386/9789241550086-eng.pdf;jsessionid $=292 \mathrm{C}$ C8FAD0E4EB62FB8002EC04F91C50? sequence $=1$

3. Nasuf AWA, Ojha S, Dorling J. Oropharyngeal colostrum in preventing mortality and morbidity in preterm infants. Cochrane Database Syst Rev 2018; 9: CD011921.

4. Helwich E, Wilińska M. Program wczesnej stymulacji laktacji dla ośrodków neonatologicznych i położniczych III poziomu referencyjnego. Standardy Medyczne Pediatria 2014; 11: 9-16.

5. World Health Organization, UNICEF. Global Nutrition Targets 2025: Breastfeeding policy brief. WHO/NMH/NHD/14.7.2014.

6. Hernández-Aguilar MT, Bartick M, Schreck, et al. ABM clinical protocol \#7: model maternity policy supportive of breastfeeding. Breastfeed Med 2018; 13.

7. Lista szpitali w Polsce odznaczonych tytułem WHO Szpital Przyjazny Dziecku. Komitet Upowszechniania Karmienia Piersią [cit. 13.05.2021]. Available from: https://laktacja.pl/ index.php/article/94,lista-szpitali-w-polsce-odznaczonychtytulem-who-szpital-przyjazny-dziecku

8. Rozporządzenie Ministra Zdrowia z dnia 16 sierpnia $2018 \mathrm{r}$. w sprawie standardu organizacyjnego opieki okołoporodowej (Dz.U. 2018 poz. 1756) [cit. 02.04.2020] Available from: http://prawo.sejm.gov.pl/isap.nsf/DocDetails. xsp?id=WDU20180001756

9. Evans A, Marinelli KA, Taylor JS. ABM Clinical Protocol \#2: guidelines for hospital discharge of the breastfeeding term newborn and mother: "The Going Home Protocol". Revised 2014. Breastfeed Med 2014; 9.
10. Nehring-Gugulska M, Żukowska-Rubik M, Pietkiewicz A. Karmienie piersią w teorii i praktyce. Podręcznik dla doradców i konsultantów laktacyjnych oraz położnych, pielęgniarek i lekarzy. Medycyna Praktyczna, Kraków 2017.

11. Del Ciampo LA, Del Ciampo IRL. Breastfeeding and the benefits of lactation for women's health. Rev Bras Ginecol Obstet 2018; 40: 354-359.

12. Sharma A. Efficacy of early skin-to-skin contact on the rate of exclusive breastfeeding in term neonates: a randomized controlled trial. Afr Health Sci 2016; 16: 790-797.

13. Polskie Towarzystwo Neonatologiczne. Standardy opieki medycznej nad noworodkiem w Polsce - zalecenia PTN (wyd. 3, zaktualizowane i uzupełnione). Media-Press, Warszawa 2019.

14. Holmes AV, McLeod AY, Bunik M. AABM clinical protocol \#5: peripartum breastfeeding management for the healthy mother and infant at term. Revision 2013. Breastfeed Med 2013; 8 .

15. Ghaheri BA, Cole M, Fausel SC, et al. Breastfeeding improvement following tongue-tie and lip-tie release: A prospective cohort study. Laryngoscope 2017; 127: 1217-1223.

16. Nehring-Gugulska M, Żukowska-Rubik M, Stobnicka-Stolarska P, et al. Protokót umiejętności ssania piersi. Postępy Neonatologii 2014; 1: 53-67.

17. Gebuza G, Jaworska K, Kaźmierczak M, et al. Najczęściej występujące problemy laktacyjne $\mathrm{w}$ okresie okołoporodowym. Polski Przegląd Nauk o Zdrowiu 2016; 2: 148-155.

18. Ghaheri BA, Cole M, Fausel SC, et al. Breastfeeding improvement following tongue-tie and lip-tie release: A prospective cohort study. Laryngoscope 2017; 127: 1217-1223.

19. Ullman FM, Fisher MD. Application of the EBP process: maximizing lactation support with minimal education. J Pediatr Nurs 2017; 33: 97-100.

20. Dz. U. 2011 Nr 174 poz. 1039 Ustawa z dnia 15 lipca 2011 r. o zawodach pielęgniarki i położnej.

21. Centrum Kształcenia Podyplomowego Pielęgniarek i Położnych, program kształcenia kursu specjalistycznego: Edukacja i wsparcie kobiety w okresie laktacji. Program przeznaczony dla położnych, Warszawa 2017 [cit. 28.02.2020]. Available from: http://ckppip.edu.pl/uploads/docs/Programy_ksztalcenia/kursy_specjalistyczne_2/Edukacja\%20i\%20wsparcie\%20 kobiety\%20w\%20okresie\%20laktacji.pdf

22. Standardy certyfikowanego doradcy laktacyjnego 2018 [cit. 15.05.2021]. Available from: http://cnol.kobiety.med.pl/pl/ doradcy-cdl/certyfikat-doradcy-cdl/standardy-cdl/

23. Informator dla kandydatów: Dla osób planujących składanie wniosku o egzamin IBCLC, które przystępują do tego egzaminu po raz pierwszy, powtarzają go lub dla Konsultantów Laktacyjnych IBCLC, którym upłynął okres przyznanych uprawnień. Styczeń 2016 [cit. 14.05.2021]. Available from URL:https://iblce.org/wp-content/uploads/2018/08/Candidate-Information-Guide_POLISH.pdf 